\title{
Activation of Anti-oxidant Nrf2 Signaling by Substituted trans Stilbenes
}

Lorraine M. Deck, ${ }^{\text {a }}$ Lisa J. Whalen, ${ }^{\text {a }}$ Lucy A. Hunsaker, ${ }^{\text {b }}$ Robert E. Royer, ${ }^{\text {b }}$ David L. Vander Jagt,

${ }^{a}$ Department of Chemistry and Chemical Biology, University of New Mexico, Albuquerque, NM 87131

${ }^{b}$ Department of Biochemistry and Molecular Biology, University of New Mexico School of Medicine, Albuquerque, NM 87131

* Corresponding author: DL Vander Jagt, dlvanderjagt@ salud.unm.edu, 505-272-5788 


\begin{abstract}
Nrf2, which is a member of the cap'n'collar family of transcription factors, is a major regulator of phase II detoxification and anti-oxidant genes as well as anti-inflammatory and neuroprotective genes. The importance of inflammation and oxidative stress in many chronic diseases supports the concept that activation of anti-oxidant Nrf2 signaling may have therapeutic potential. A number of Nrf2 activators have entered into clinical trials. Nrf2 exists in the cytosol in complex with its binding partner Keap1, which is a thiol-rich redox-sensing protein. In response to oxidative and other stress, select cysteine residues of Keap1 are modified, which weakens the interaction between Nrf2 and Keap1 and allows Nrf2 to enter the nucleus. Numerous Nrf2-activating chemicals, including a number of natural products, are electrophiles that modify Keap1, often by Michael addition, leading to activation of Nrf2. One concern with the design of Nrf2 activators that are electrophilic covalent modifiers of Keap1 is the issue of selectivity. In the present study, substituted trans stilbenes were identified as activators of Nrf2. These activators of Nrf2 are not highly electrophilic and therefore are unlikely to activate Nrf2 through covalent modification of Keap1. Dose-response studies demonstrated that a range of substituents on either ring of the trans stilbenes, especially fluorine and methoxy substituents, influenced not only the sensitivity to activation, reflected in $\mathrm{EC}_{50}$ values, but also the extent of activation, which suggests that multiple mechanisms are involved in the activation of Nrf2. The stilbene backbone appears to be a privileged scaffold for development of a new class of Nrf2 activators.
\end{abstract}




\section{Introduction}

Inflammation and oxidative stress are associated with most chronic diseases, including neurodegenerative and neuropsychiatric diseases. In Alzheimer's disease (AD), for example, focal activation of microglia, the resident brain macrophage, which is a source of proinflammatory signals and oxidative stress, is seen consistently in the vicinity of plaques, both in pathological samples from $\mathrm{AD}$ patients and in animal models. ${ }^{1-5} \mathrm{~A}$ normal response to oxidative stress is activation of a number of anti-oxidant genes to counteract the development of oxidative stress. The promoters for these anti-oxidant genes commonly have an anti-oxidant response element (ARE) where transcription factor Nuclear factor erythroid 2 related factor 2 (Nrf2) can bind to induce gene expression.

Nrf2, which is a member of the cap'n'collar family of transcription factors, is a major regulator of phase II detoxification and anti-oxidant genes as well as anti-inflammatory and

neuroprotective genes. ${ }^{6-14}$ In unstressed cells, Nrf2 is retained in the cytosol through formation of a complex between Nrf2, Kelch-like ECH associated protein 1 (Keap1), and Cul3, which is an adaptor to link Nrf2 to an E3 ubiquitin ligase complex. Nrf2 is continuously synthesized and then degraded by ubiquitination and proteosomal degradation, which limits the cytosolic concentration of Nrf2. In response to oxidative and other stress, select cysteine residues of Keap1 are modified, which weakens the interaction between Nrf2 and Keap1. This allows newly synthesized Nrf2 to accumulate and translocate to the nucleus where it interacts with small Maf proteins and subsequently binds to promoters with ARE sequences. Nrf2 can also be released from Keap1 by covalent modification of Keap1 by electrophiles.

Nrf2 is widespread in the CNS and is recognized as an important regulator of brain inflammation. In animal models with Nrf2 deficiency, neurodegeneration is observed, especially in areas with high oxidative metabolism. ${ }^{7,15}$ In animal models of stroke and traumatic brain injury, Nrf2 deficiency leads to more intense inflammation and more severe injury. ${ }^{16,17}$ In humans, Nrf2 declines with age and may contribute to age as a risk factor for neurological disease. Activation of Nrf2 in astrocytes can protect neurons from oxidative stress. ${ }^{18}$ The impaired translocation of Nrf2 to the nucleus in neurons from AD subjects ${ }^{19}$ suggests that defects in Nrf2 activation may play a major role in the development of oxidative damage in AD brains.

Recently we reported that the natural product resveratrol, which is a trans stilbene, and a synthetic trans stilbene ((E)-2-fluoro-4'-methoxystilbene, designated LD55) were effective at reducing both brain inflammation and plaque accumulation in a transgenic animal model of AD. ${ }^{20}$ LD55 was selected based upon its ability to inhibit activation of the pro-inflammatory transcription factor NF- $\kappa \mathrm{B}$ in a reporter cell-based assay and on its ability to inhibit expression of pro-inflammatory signals in a microglia cell line in response to LPS. ${ }^{21}$ Resveratrol also inhibits the activation of NF- $\mathrm{KB} .{ }^{22}$ In the present study, we demonstrate that $\mathbf{L D 5 5}$ also shares 
with resveratrol the ability to activate Nrf2, and we describe the activities of a series of trans stilbenes that were compared to resveratrol and LD55 for their abilities to promote activation of Nrf2 in reporter assays. The natural product isothiocyanate sulforaphane, which is a wellestablished activator of $\mathrm{Nrf} 2,{ }^{23}$ was used as a positive control.

\section{Materials and methods}

\section{Scheme 1}

\subsection{Synthesis of substituted trans stilbenes}

The synthesis of 56 substituted trans (E)-stilbenes (Table 1) was accomplished using HornerWadsworth-Emmons (HWE) olefination chemistry. ${ }^{24}$ The starred compounds in Table 1 are new to the literature, and their synthesis is described in Scheme $1 .{ }^{25}$ Synthesis of the other compounds in Table 1 was accomplished using a method reported previously. ${ }^{21} \mathrm{HWE}$ chemistry was used to avoid formation of a mixture of $\mathrm{E}$ and $\mathrm{Z}$ isomers and formation of triphenylphosphine oxide, which complicates the purification process.

The required phosphonate ester starting materials were prepared in high yields by the classical solvent free Michaelis-Arbuzov reaction of substituted benzyl chlorides or bromides with triethylphosphite at $130^{\circ} \mathrm{C}{ }^{26}$ Removal of excess triethylphosphite and chloroethane or bromoethane product was carried out by vacuum distillation. Further purification using a short silica gel column and eluting with ethyl acetate/hexane provided pure phosphonate esters as oils. $^{27}$

Reaction of the appropriately substituted diethyl benzylphosphonate ester with a corresponding freshly distilled substituted benzaldehyde in dry tetrahydrofuran using sodium hydride as the base (Scheme 1) afforded the 20 new substituted stilbenes (Table 1) exclusively in the E conformation. There was no detectable $\mathrm{Z}$ isomer, and the trans geometry of the substituted stilbenes was confirmed by the coupling constants of approximately $16.5 \mathrm{~Hz}$ for the olefinic protons in the proton NMR spectra. The reaction conditions allowed for a straightforward workup since the diethylphosphoric acid byproducts are water-soluble and were easily removed by extraction. Purification of the benzaldehydes and phosphonate esters was found to be critical for obtaining good yields and pure products.

\section{Table 1}




\section{Results and discussion}

\subsection{Activation of Nrf2 by resveratrol, LD55 and sulforaphane}

Resveratrol, LD55 and sulforaphane were compared in an Nrf2-ARE reporter-HepG2 stable cell line, which was designed for use as a luciferase reporter-based assay for activators of Nrf2. The ability of both resveratrol and LD55 to activate Nrf2 signaling extends the known activities of these two trans stilbenes to include both anti-inflammatory activities as inhibitors of the proinflammatory NF- $\mathrm{kB}$ signaling pathway as well as anti-oxidative stress activities as activators of Nrf2. It is noteworthy that the extent of activation of Nrf2 differs for these three activators (Table 2). LD55 was 5 -fold better than resveratrol in the extent of Nrf2 activation. Concentrations that produced $50 \%$ activation $\left(\mathrm{EC}_{50}\right)$ were obtained from dose-response curves. Resveratrol and LD55 show low $\mathrm{EC}_{50}$ values $(5.4 \mu \mathrm{M})$, comparable to sulforaphane $(1.2 \mu \mathrm{M})$ (Table 2). The fact that these activators of $\mathrm{Nrf} 2$ can vary both in their $\mathrm{EC}_{50}$ values and in the extent of activation requires that both of these factors be considered in evaluation of the activities of Nrf2 activators.

\subsection{Activation of Nrf2 by monofluoro trans stilbenes}

A library of substituted trans stilbenes was screened to identify activators of Nrf2. With few exceptions, such as resveratrol, only compounds with fluorine or methoxy substituents showed significant activity. From this screen, a group of 56 substituted trans stilbenes was identified as activators of Nrf2. A series of monofluoro trans stilbenes was compared with resveratrol and LD55. The series was screened at $15 \mu \mathrm{M}$ concentrations of the compounds, a concentration that did not produce any solubility problems and was sufficiently higher than the $\mathrm{EC}_{50}$ values to allow a comparison of the differing extents of activation (Table 2). All of these monofluoro trans stilbenes were activators of Nrf2, although the extent of activation varied almost 20-fold. Many of the compounds were better Nrf2 activators than sulforaphane and were much better than resveratrol. The $\mathrm{EC}_{50}$ values for these monofluoro trans stilbenes ranged from $0.7 \mu \mathrm{M}$ (trans stilbene $\underline{\mathbf{2}}$ ) to $12.4 \mu \mathrm{M}$ (trans stilbene $\underline{\mathbf{4}}$ ). Comparison of trans stilbenes $\underline{\mathbf{2}}, \underline{\mathbf{3}}$ and $\underline{\mathbf{4}}$, all of which contain a single fluorine substituent on one of the aromatic rings and no substituent on the other ring, suggests that fluorine substitution in the ortho position, as in LD55, is preferred. However, this is not consistently observed. Comparison of $\mathbf{L D 5 5}$ with $\underline{\mathbf{5}}$ and $\underline{\mathbf{6}}$, all of which contain a para methoxy substituent, shows little effect of altering the position of the fluorine on $\mathrm{EC}_{50}$ values which ranged from 4.2 to $8.9 \mu \mathrm{M}$ (Table 2). Likewise, altering the positions of both the fluorine and methoxy substituents as in LD55, $\underline{\mathbf{5}}, \underline{\mathbf{6}}, \underline{\mathbf{1 0}} \underline{\mathbf{1 3}}$, all of which are isomers, has a modest effect with $\mathrm{EC}_{50}$ values ranging from 2.3 to $8.9 \mu \mathrm{M}$. The extent of activation, however, differs markedly. For example, isomer $\underline{\mathbf{1 0}}$ is activated almost 10 -fold more than isomer $\underline{\mathbf{6}}$ (Table 2). 
Replacing the methoxy substituent with a methyl substituent $(\mathbf{7}, \mathbf{8}$ and $\mathbf{9})$ lowers $\mathrm{EC}_{50}$ to low or even sub-micromolar values.

\section{Table 2}

\subsection{Activation of Nrf2 by polyfluoro trans stilbenes}

A series of polyfluoro trans stilbenes was compared with resveratrol and LD55. EC $_{50}$ values ranged from 0.3 to $>15 \mu \mathrm{M}$ (Table 3 ) and extent of activation varied about 5-fold, with all of these stilbenes better than resveratrol with respect to fold activation. As with the monofluoro trans stilbenes, the location of the fluorine substituents markedly affected $\mathrm{EC}_{50}$ values and fold activations, but not in readily predictable patterns. For example, $\mathrm{EC}_{50}$ for the difluoro trans stilbene 33 is sub-micromolar $(0.65 \mu \mathrm{M})$ while $\mathrm{EC}_{50}$ for its isomer 25 is $>15 \mu \mathrm{M}$. Likewise, the $\mathrm{EC}_{50}$ for the trifluoro trans stilbene 34 is sub-micromolar $(0.3 \mu \mathrm{M})$ while $\mathrm{EC}_{50}$ for its isomer 24 is $>15 \mu \mathrm{M}$. Multiple trifluoro isomers $(\mathbf{3 4}, \mathbf{3 5}, \mathbf{3 8})$ exhibited sub-micromolar $\mathrm{EC}_{50}$ values. Isomer 34 was the most effective activator when expressed as fold activation divided by $\mathrm{EC}_{50}$. The conclusion from the data in Tables 2 and 3 is that all of these fluorine substituted trans stilbenes demonstrate measurable activity as activators of $\mathrm{Nrf} 2$.

\section{Table 3}

\subsection{Activation of Nrf2 by nonfluoro trans stilbenes}

A series of substituted trans stilbenes, most of which contained methoxy groups at one or more positions, demonstrated activity as activators of Nrf2, as shown in Table 4. $\mathrm{EC}_{50}$ values ranged from $0.8 \mu \mathrm{M}$ (trans stilbene 56) to $>15 \mu \mathrm{M}$. All of these trans stilbenes were as good as or better than sulforaphane with respect to fold activation and were much better than resveratrol. Compounds $\mathbf{5 1}$ and $\mathbf{5 4}$ demonstrated the highest fold activations of all of the trans stilbenes, 69 and 65.5 fold, respectively. The results from this study support the conclusion that the stilbene scaffold is a useful structure upon which to explore chemical space to develop activators of Nrf2, especially those that include fluorine and methoxy functional groups as in LD55.

\section{Table 3}

The importance of inflammation and oxidative stress in many chronic diseases supports the concept that activation of anti-oxidant Nrf2 signaling may have therapeutic potential. Cells have developed complex adaptive responses to oxidative stress to maintain redox homeostasis and to reduce oxidative stress. ${ }^{45}$ Stress activation of Nrf2 may be the result of exposure to xenobiotics, including many natural products. ${ }^{46}$ Many of these Nrf2 activators are electrophiles. One of the 
major mechanisms of Nrf2 activation is through covalent modification of select cysteine sulfhydryl residues in Keap1. Numerous Nrf2-activating chemicals, including natural products such as sulforaphane, are electrophiles that modify Keap1, often by Michael addition. ${ }^{47-49}$ Cysteine residues 273, 288 and 151 appear to be especially important targets, as determined by site-directed mutagenesis. Resveratrol and other natural product phenols activate Nrf2 after oxidation to electrophilic quinones that contain Michael acceptor functionalities. ${ }^{49}$ Moreover, some natural product phenols including resveratrol can activate Nrf2 by additional mechanism, such as increasing the level of Nrf2 mRNA. ${ }^{49}$

A number of Nrf2 activators have entered into clinical trials. Bardoxolone methyl, an oleanolic acid-derived synthetic triterpene, is a potent Nrf2 activator that was evaluated for its ability to slow progression to end-stage renal disease in patients with type 2 diabetes and stage 4 chronic kidney disease. Bardoxolone methyl is able to modify Keap1 as a Michael acceptor. The clinical trial was terminated in phase III owing to an increase in heart failure. ${ }^{50}$ Dimethyl fumarate, a simple derivative of the metabolic intermediate fumaric acid, has recently been FDA-approved for the treatment of relapsing-remitting multiple sclerosis. ${ }^{51}$ Dimethyl fumarate is active as the monomethyl derivative formed by the action of non-specific esterases. Monomethyl fumarate modifies Keap1 through electrophilic addition. For both bardoxolone methyl and dimethyl fumarate, however, mechanisms in addition to modification of Keap1 may play a role in activation of Nrf2.

One concern with the design of Nrf2 activators that are electrophilic covalent modifiers of Keap1 is the issue of selectivity. Bardoxolone methyl, for example, has been shown to react with multiple targets. ${ }^{52}$ To address this concern, a number of recent studies have focused on development of non-electrophilic activators of $\mathrm{Nrf} 2,{ }^{53}$ aided by the availability of the crystal structures of the BTB domain of Keap1, which contains residue cysteine151 that is the target for covalent modification by bardoxolone methyl, ${ }^{54}$ the Kelch domain of Keap $1^{55}$ and the Keap1Nrf2 interface. ${ }^{56}$ Peptide inhibitors of the Keap1-Nrf2 protein-protein interaction have been described $^{57,58}$ as well as a variety of small molecules that inhibit the Keap1-Nrf2 interaction. ${ }^{59-62}$

There are additional mechanisms for activation of Nrf2. Epigenetic modifications of $\mathrm{CpG}$ methylation status of Nrf2 by the anti-cancer drug 3,3'-diindolylmethane resulted in enhanced expression of Nrf2 and of Nrf2-target genes in cell-based studies. ${ }^{63}$ This was suggested as an explanation for the chemopreventive activity of this drug. The promoter of the gene encoding Nrf2 contains XRE sequences, which can recruit the aromatic hydrocarbon receptor AhR; this allows the Nrf2 gene to be activated by polycyclic aromatic hydrocarbons. ${ }^{64}$ The promoter of the Nrf2 gene also contains ARE-like sequences, which allows Nrf2 to regulate its own expression. ${ }^{65}$ The Nrf2 promoter also contains an NF- $\mathrm{KB}$ binding site, which allows activation of Nrf2 by proinflammatory stimuli. ${ }^{66}$ 
The autophagy cargo receptor and signaling adaptor protein p62 contains a binding site for Keap1. The attraction of Keap1 to this site is further regulated by phosphorylation by mTORC1, which leads to autophagosome -mediated destruction of Keap1 and activation of Nrf2 ${ }^{67,68}$ This is one example of proteins other than Nrf2 that interact specifically with Keap1, which indicates a broad role for Keap1 and a complex set of mechanisms that impact Nrf2 levels. ${ }^{69}$ There are, therefore, numerous targets for potential activators of Nrf2.

In the present study, we identified numerous substituted trans stilbenes as activators of Nrf2, especially trans stilbenes with fluorine and/or methoxy ring substituents. The double bond in the trans stilbene scaffold is generally a low-reactivity center which would be unlikely to modify Keap1 by electrophilic addition. It remains to be determined which site(s) is the target for activation of Nrf2 by substituted trans stilbenes. Likewise, it remains to be determined how different trans stilbenes produce markedly different fold activations, which likely involves multiple mechanisms.

\section{Conclusions}

Substituted trans stilbenes represent promising compounds for the development of potential drugs that target oxidative stress in chronic diseases, through activation of the anti-oxidant Nrf2 signaling pathway.

\section{Experimental}

\subsection{Reporter Assay:}

A Nrf2-ARE reporter-HepG2 stable cell line (BPS Bioscience, San Diego, CA) is grown in a humidified atmosphere at $37^{\circ} \mathrm{C}$ in $5 \% \mathrm{CO}_{2} / 95 \%$ air. The cells are maintained in MEM medium with Earles balanced salts and L-glutamine supplemented with 10\% fetal bovine serum (FBS), 1 $\mathrm{mM}$ sodium pyruvate, $1 \%$ non-essential amino acids, 100 units $/ \mathrm{ml}$ penicillin, $100 \mu \mathrm{g} / \mathrm{ml}$ streptomycin, and $400 \mu \mathrm{g} / \mathrm{ml}$ Geneticin. One day prior to treatment, the Nrf2-ARE cells are plated into 24-well cell culture plates at approximately $30 \%$ confluency in the above media without Geneticin. The following day, fresh media with or without substituted trans stilbene or sulforaphane is applied to the cells. DMSO concentrations are kept at $0.1 \%$. The cells are again placed in a humidified atmosphere at $37^{\circ} \mathrm{C}$ in $5 \% \mathrm{CO}_{2} / 95 \%$ air for 5 hours. Plate wells are gently washed with phosphate buffered saline (PBS) $\mathrm{pH} 7.4$ and lysed with 1x passive lysis buffer (Promega, Madison, WI, USA). The subsequent lysates are analyzed with the Luciferase Assay System (Promega) utilizing a GloMax 20/20 luminometer (Promega, Sunnyvale, CA, USA). The firefly luciferase relative light units are normalized to protein $(\mathrm{mg} / \mathrm{ml})$ with BCATM Protein Assay Kit protein (Pierce, Rockford, IL, USA) 


\subsection{Synthesis:}

Reagents were purchased from commercial sources (Aldrich, Acros). Tetrahydrofuran was distilled from lithium aluminum hydride. Thin layer chromatography was carried out on silica gel $60 \mathrm{~F} 254$ plates. All compounds were shown to be $>98 \%$ pure by ${ }^{1} \mathrm{H}$ NMR and/or ${ }^{13} \mathrm{C}$ NMR unless otherwise noted. Column chromatographic separations were performed by using EM type 60 silica gel (230-400 mesh). Melting points were taken on a Thomas-Hoover Uni-Melt capillary melting point apparatus and reported uncorrected. Unless otherwise noted, ${ }^{1} \mathrm{H}$ spectra were recorded by using $\mathrm{CDCl}_{3}$ solutions at $300 \mathrm{MHz} ;{ }^{13} \mathrm{C}$ NMR spectra were recorded in $\mathrm{CDCl}_{3}$ at 75 $\mathrm{MHz} ;{ }^{19} \mathrm{~F}$ were recorded in $\mathrm{CDCl}_{3}$ at $282 \mathrm{MHz}$. Chemical shifts are reported in ppm relative to $\mathrm{CDCl}_{3}$ at $7.24 \mathrm{ppm}$ for ${ }^{1} \mathrm{H}$ NMR and $77.0 \mathrm{ppm}$ for ${ }^{13} \mathrm{C}$ NMR and the external standard hexafluorobenzene for ${ }^{19} \mathrm{~F}$ NMR at $-164.9 \mathrm{ppm}$. Peak assignments were made with the aid of DEPT spectra. ${ }^{1} \mathrm{H}$ NMR data are reported as follows: chemical shift, multiplicity ( $\mathrm{s}=$ singlet, $\mathrm{d}=$ doublet, $\mathrm{t}=$ triplet, $\mathrm{q}=$ quartet, $\mathrm{dd}=$ doublet of doublets, $\mathrm{td}=$ triplet of doublets, $\mathrm{m}=$ multiplet $)$, coupling constant $(\mathrm{J}$ in $\mathrm{Hz}$ ) and integration. High resolution mass spectra (HRMS) were obtained at the UNM Mass Spectrometry Facility, Albuquerque, New Mexico.

\section{General Procedure for Synthesis of Phosphonate Esters}

Benzyl chloride or benzyl bromide derivatives (1eq) were added to triethylphosphite (1.5 eq) and heated to $130^{\circ} \mathrm{C}$ for $20 \mathrm{~h}$. After cooling, the resulting crude product was distilled in vacuo to remove excess triethylphosphite and ethyl chloride or ethyl bromide. Purification by filtration through a pad of silica gel (70\% ethyl acetate/30\% hexanes) gave the phosphonate ester products as colorless oils.

\section{General Procedure for Synthesis of Stilbenes}

The appropriately substituted phosphonate ester $(10 \mathrm{mmol})$ was dissolved in dry tetrahydrofuran $(20 \mathrm{ml})$ and stirred at $0-5^{\circ} \mathrm{C}$. Sodium hydride $(25 \mathrm{mmol})$ was added to the solution slowly and after thirty minutes the appropriate freshly distilled aldehyde $(10 \mathrm{mmol})$ in tetrahydrofuran (30 $\mathrm{ml}$ ) was added dropwise. The mixture was allowed to stir at room temperature overnight. In order to increase the yield, compounds 35, 37 and 40 were heated under reflux for 3-4 hours. The mixture was cooled and quenched with ice water $(10 \mathrm{ml})$ and poured onto ice. Dilute hydrochloric acid (1M) was added until acidic and the solution was extracted with ethyl acetate $(4 \times 50 \mathrm{ml})$. The combined organic layers were washed with saturated salt and dried over magnesium sulfate. Filtration and evaporation of the ethyl acetate afforded crude stilbene products as oils or solids. The solids were crystallized from $95 \%$ ethanol to afford crystalline stilbenes. The oils were chromatographed on silica gel using methylene chloride to give pure products. 
(E)-1-Fluoro-2-(2-methoxystyryl)benzene 10: 98\% yield, white crystals; mp $34-35{ }^{\circ} \mathrm{C} ;{ }^{1} \mathrm{H}$ NMR $\left(\mathrm{CDCl}_{3}, 300 \mathrm{MHz}\right): \delta 7.66(\mathrm{dt}, J=7.8,1.6 \mathrm{~Hz}, 1 \mathrm{H}), 7.62(\mathrm{dd}, J=7.6,1.5 \mathrm{~Hz}, 1 \mathrm{H}), 7.54(\mathrm{~d}, J=$ $16.6 \mathrm{~Hz}, 1 \mathrm{H}), 7.27(\mathrm{~d}, J=16.6 \mathrm{~Hz}, 1 \mathrm{H}), 7.22(\mathrm{~m}, 2 \mathrm{H}), 7.13(\mathrm{dt}, J=7.5,1.3 \mathrm{~Hz}, 1 \mathrm{H}), 7.05(\mathrm{dt}, J=$ 8.0, $1.3 \mathrm{~Hz}, 1 \mathrm{H}), 6.98(\mathrm{t}, J=7.4 \mathrm{~Hz}, 1 \mathrm{H}), 6.91(\mathrm{~d}, J=8.3 \mathrm{~Hz}, 1 \mathrm{H}), 3.88(\mathrm{~s}, 3 \mathrm{H}) .{ }^{13} \mathrm{C}$ NMR $\left(\mathrm{CDCl}_{3}, 75 \mathrm{MHz}\right): \delta 160.5(\mathrm{~d}, J=247.7 \mathrm{~Hz}), 157.2(\mathrm{~s}), 129.2(\mathrm{~s}), 128.6(\mathrm{~d}, J=8.4 \mathrm{~Hz}), 127.0(\mathrm{~d}$, $J=3.4 \mathrm{~Hz}), 126.7$ (s), 126.5 (s), $126.0(\mathrm{~d}, J=12.1 \mathrm{~Hz}), 125.7$ (d, $J=3.6 \mathrm{~Hz}), 124.2(\mathrm{~d}, J=3.1$ $\mathrm{Hz}), 121.1(\mathrm{~d}, J=4.0 \mathrm{~Hz}), 120.9(\mathrm{~s}), 115.5(\mathrm{~d}, J=22.2 \mathrm{~Hz}), 110.8(\mathrm{~s}), 55.7(\mathrm{~s}) .{ }^{19} \mathrm{~F}\left(\mathrm{CDCl}_{3}, 282\right.$ MHz): $\delta-116.9$ (s, 1F). HRMS (EI) calcd for $\mathrm{C}_{15} \mathrm{H}_{13} \mathrm{FO}[\mathrm{M}]^{+}$: 228.0950; found, 228.0950.

(E)-1-(3-Fluorostyryl)-2,3-dimethoxybenzene 16: $98 \%$ yield, oil; ${ }^{1} \mathrm{H} \mathrm{NMR}\left(\mathrm{CDCl}_{3}, 300 \mathrm{MHz}\right)$ : $\delta$ $7.45(\mathrm{~d}, J=16.5 \mathrm{~Hz}, 1 \mathrm{H}), 7.27(\mathrm{~m}, 3 \mathrm{H}), 7.23(\mathrm{dd}, J=7.9,1.3 \mathrm{~Hz}, 1 \mathrm{H}), 7.08(\mathrm{~d}, J=16.5 \mathrm{~Hz}, 1 \mathrm{H})$, $7.06(\mathrm{t}, J=8.1 \mathrm{~Hz}, 1 \mathrm{H}), 6.96(\mathrm{~m}, 1 \mathrm{H}), 6.86(\mathrm{dd}, J=8.1,1.4 \mathrm{~Hz}, 1 \mathrm{H}), 3.88(\mathrm{~s}, 3 \mathrm{H}), 3.87(\mathrm{~s}, 3 \mathrm{H})$. ${ }^{13} \mathrm{C} \mathrm{NMR}\left(\mathrm{CDCl}_{3}, 75 \mathrm{MHz}\right): \delta 163.2(\mathrm{~d}, J=245.1 \mathrm{~Hz}), 153.3(\mathrm{~s}), 147.3(\mathrm{~s}), 140.1(\mathrm{~d}, J=7.6$ $\mathrm{Hz}), 131.0(\mathrm{~s}), 130.1$ (d, $J=8.4 \mathrm{~Hz}), 128.7(\mathrm{~s}), 124.3(\mathrm{~s}), 124.2(\mathrm{~s}), 122.6(\mathrm{~s}), 117.9$ (s), 114.4 (d, $J=21.5 \mathrm{~Hz}), 112.9(\mathrm{~d}, J=21.8 \mathrm{~Hz}), 111.8(\mathrm{~s}), 61.2(\mathrm{~s}), 56.0(\mathrm{~s}) .{ }^{19} \mathrm{~F}\left(\mathrm{CDCl}_{3}, 282 \mathrm{MHz}\right): \delta-111.9$ (s, 1F). HRMS (EI) calcd for $\mathrm{C}_{16} \mathrm{H}_{15} \mathrm{FO}_{2}[\mathrm{M}]^{+}: 258.1056$; found, 258.1058 .

(E)-1-(4-Fluorostyryl)-2,3-dimethoxybenzene 17: 87\% yield, white crystals; mp 50-51 ${ }^{\circ} \mathrm{C} ;{ }^{1} \mathrm{H}$ NMR $\left(\mathrm{CDCl}_{3}, 300 \mathrm{MHz}\right): \delta 7.50(\mathrm{dd}, J=8.4,5.6 \mathrm{~Hz}, 2 \mathrm{H}), 7.36(\mathrm{~d}, J=16.5 \mathrm{~Hz}, 1 \mathrm{H}), 7.21(\mathrm{~d}, J=$ $7.8 \mathrm{~Hz}, 1 \mathrm{H}), 7.07(\mathrm{~d}, J=16.4 \mathrm{~Hz}, 1 \mathrm{H}), 7.04(\mathrm{~m}, 3 \mathrm{H}), 6.83(\mathrm{~d}, J=7.6 \mathrm{~Hz}, 1 \mathrm{H}), 3.87(\mathrm{~s}, 3 \mathrm{H}), 3.85$ (s, 3H). ${ }^{13} \mathrm{C}$ NMR $\left(\mathrm{CDCl}_{3}, 75 \mathrm{MHz}\right): \delta 162.4(\mathrm{~d}, J=247.1 \mathrm{~Hz}), 153.2(\mathrm{~s}), 147.0(\mathrm{~s}), 133.9(\mathrm{~d}, 2.9$ $\mathrm{Hz}), 131.4(\mathrm{~s}), 128.7(\mathrm{~s}), 128.2(\mathrm{~d}, J=7.9 \mathrm{~Hz}), 124.2(\mathrm{~s}), 122.8(\mathrm{~s}), 117.8(\mathrm{~s}), 115.6(\mathrm{~d}, J=21.6$ $\mathrm{Hz}), 111.5(\mathrm{~s}), 61.1(\mathrm{~s}), 55.8(\mathrm{~s}) .{ }^{19} \mathrm{~F}\left(\mathrm{CDCl}_{3}, 282 \mathrm{MHz}\right): \delta-112.7$ (s, 1F). HRMS (EI) calcd for $\mathrm{C}_{16} \mathrm{H}_{15} \mathrm{FO}_{2}[\mathrm{M}]^{+}$: 258.1056; found, 258.1060.

(E)-2-(4-Fluorostyryl)-1,4-dimethoxybenzene 18: 74\% yield, white crystals; mp 58-59 ${ }^{\circ} \mathrm{C} ;{ }^{1} \mathrm{H}$ NMR (CDCl $3,300 \mathrm{MHz}): \delta 7.49$ (dd, $J=8.7,5.5 \mathrm{~Hz}, 2 \mathrm{H}), 7.37(\mathrm{~d}, J=16.4 \mathrm{~Hz}, 1 \mathrm{H}), 7.13(\mathrm{~d}, J=$ $2.6 \mathrm{~Hz}, 1 \mathrm{H}), 7.05(\mathrm{~d}, J=16.4 \mathrm{~Hz}, 1 \mathrm{H}), 7.03(\mathrm{t}, J=8.7 \mathrm{~Hz}, 2 \mathrm{H}), 6.80(\mathrm{~m}, 2 \mathrm{H}), 3.83(\mathrm{~s}, 3 \mathrm{H}), 3.81$ $(\mathrm{s}, 3 \mathrm{H}) .{ }^{13} \mathrm{C} \mathrm{NMR}\left(\mathrm{CDCl}_{3}, 75 \mathrm{MHz}\right): \delta 162.3(\mathrm{~d}, J=247.0 \mathrm{~Hz}), 153.8(\mathrm{~s}), 151.4(\mathrm{~s}), 134.0(\mathrm{~d}, 3.1$ $\mathrm{Hz}), 128.1(\mathrm{~s}), 128.0(\mathrm{~d}, J=7.7 \mathrm{~Hz}), 123.1(\mathrm{~s}), 115.6(\mathrm{~d}, J=21.6 \mathrm{~Hz}), 113.7(\mathrm{~s}), 112.2(\mathrm{~s}), 111.7$ (s), $56.2(\mathrm{~s}), 55.7(\mathrm{~s}) .{ }^{19} \mathrm{~F}\left(\mathrm{CDCl}_{3}, 282 \mathrm{MHz}\right): \delta-112.9$ (s, 1F). HRMS (EI) calcd for $\mathrm{C}_{16} \mathrm{H}_{15} \mathrm{FO}_{2}$ $[\mathrm{M}]^{+}:$258.1056; found, 258.1057 .

(E)-1,2-Difluoro-4-(4-methylstyryl)benzene 22: 97\% yield, white crystals; mp 90-92 ${ }^{\circ} \mathrm{C} ;{ }^{1} \mathrm{H}$ NMR $\left(\mathrm{CDCl}_{3}, 300 \mathrm{MHz}\right): \delta 7.38(\mathrm{~d}, J=8.1 \mathrm{~Hz}, 2 \mathrm{H}), 7.29(\mathrm{~m}, 1 \mathrm{H}), 7.16(\mathrm{~d}, J=8.1 \mathrm{~Hz}, 2 \mathrm{H}), 7.13$ $(\mathrm{m}, 2 \mathrm{H}), 6.99(\mathrm{~d}, J=16.4 \mathrm{~Hz}, 1 \mathrm{H}), 6.92(\mathrm{~d}, J=16.4 \mathrm{~Hz}, 1 \mathrm{H}), 2.36(\mathrm{~s}, 3 \mathrm{H}) .{ }^{13} \mathrm{C} \mathrm{NMR}\left(\mathrm{CDCl}_{3}, 75\right.$ MHz): $\delta 151.7(\mathrm{dd}, J=69.7,13.3 \mathrm{~Hz}), 148.5(\mathrm{dd}, \mathrm{J}=70.7,13.3 \mathrm{~Hz}), 138.0(\mathrm{~s}), 134.9(\mathrm{t}, J=5.0$ Hz), 133.9 (s), 129.7 (s), 129.5 (s), 126.5 (s), 125.5 (s), 122.6 (dd, $J=6.1,2.9 \mathrm{~Hz}), 117.3$ (d, $J=$ 
$17.5 \mathrm{~Hz}), 114.5(\mathrm{~d}, J=17.6 \mathrm{~Hz}), 21.3(\mathrm{~s}) .{ }^{19} \mathrm{~F}\left(\mathrm{CDCl}_{3}, 282 \mathrm{MHz}\right): \delta-136.3(\mathrm{~d}, J=20.9 \mathrm{~Hz}, 1 \mathrm{~F}),-$ 137.7 (d, $J=20.9 \mathrm{~Hz}, 1 \mathrm{~F})$. HRMS (EI) calcd for $\mathrm{C}_{15} \mathrm{H}_{12} \mathrm{~F}_{2}[\mathrm{M}]^{+}:$230.0907; found, 230.0911 .

(E)-1,4-Difluoro-2-(4-methoxystyryl)benzene 23: 60\% yield, pale yellow crystals; mp 109-110 ${ }^{\circ} \mathrm{C} ;{ }^{1} \mathrm{H}$ NMR $\left(\mathrm{CDCl}_{3}, 300 \mathrm{MHz}\right): \delta 7.46(\mathrm{~d}, J=8.6 \mathrm{~Hz}, 2 \mathrm{H}), 7.25(\mathrm{~m}, 1 \mathrm{H}), 7.06(\mathrm{~s}, 2 \mathrm{H}), 6.98(\mathrm{~m}$, $1 \mathrm{H}), 6.89(\mathrm{~d}, J=8.6 \mathrm{~Hz}, 2 \mathrm{H}), 6.86(\mathrm{~m}, 1 \mathrm{H}), 3.81(\mathrm{~s}, 3 \mathrm{H}) .{ }^{13} \mathrm{C} \mathrm{NMR}\left(\mathrm{CDCl}_{3}, 75 \mathrm{MHz}\right): \delta 159.8$ (s), 159.2 (d, $J=200.2 \mathrm{~Hz}), 156.0(\mathrm{~d}, J=201.6 \mathrm{~Hz}), 131.5$ (d, $J=3.9 \mathrm{~Hz}), 129.5$ (s), 128.1 (s), $127.0(\mathrm{dd}, J=14.5,8.2 \mathrm{~Hz}), 117.6(\mathrm{~s}), 116.7$ (dd, $J=25.4,8.7 \mathrm{~Hz}), 114.5$ (dd, $J=24.5,9.0 \mathrm{~Hz}$ ), $114.2(\mathrm{~s}), 112.4(\mathrm{dd}, J=24.6,3.8 \mathrm{~Hz}), 55.3(\mathrm{~s}) .{ }^{19} \mathrm{~F}\left(\mathrm{CDCl}_{3}, 282 \mathrm{MHz}\right): \delta-117.7$ (d, $J=17.2 \mathrm{~Hz}$, $1 \mathrm{~F}),-122.9(\mathrm{~d}, J=17.2 \mathrm{~Hz}, 1 \mathrm{~F})$. HRMS (EI) calcd for $\mathrm{C}_{15} \mathrm{H}_{12} \mathrm{~F}_{2} \mathrm{O}[\mathrm{M}]^{+}:$246.0856; found, 246.0852 .

(E)-1,2-Difluoro-4-(2-fluorostyryl)benzene 24 : $82 \%$ yield, white crystals; mp $85-86{ }^{\circ} \mathrm{C} ;{ }^{1} \mathrm{H}$ NMR $\left(\mathrm{CDCl}_{3}, 300 \mathrm{MHz}\right): \delta 7.56(\mathrm{dt}, J=7.7,1.6 \mathrm{~Hz}, 1 \mathrm{H}), 7.33(\mathrm{dt}, J=7.7,1.8 \mathrm{~Hz}, 1 \mathrm{H}), 7.23(\mathrm{~m}, 2 \mathrm{H})$, $7.17(\mathrm{~d}, J=16.4 \mathrm{~Hz}, 1 \mathrm{H}), 7.10(\mathrm{~m}, 3 \mathrm{H}), 7.05(\mathrm{~d}, J=16.3 \mathrm{~Hz}, 1 \mathrm{H}) .{ }^{13} \mathrm{C} \mathrm{NMR}\left(\mathrm{CDCl}_{3}, 75 \mathrm{MHz}\right)$ : $\delta 160.7(\mathrm{~d}, J=247.9 \mathrm{~Hz}), 152.1(\mathrm{dd}, J=44.2,12.0 \mathrm{~Hz}), 148.8(\mathrm{dd}, J=46.6,12.0 \mathrm{~Hz}), 134.7(\mathrm{t}, J$ = 6.2 Hz), $129.4(\mathrm{~d}, J=8.4 \mathrm{~Hz}), 128.9(\mathrm{~s}), 127.3(\mathrm{~d}, J=3.2 \mathrm{~Hz}), 124.7$ (d, J=11.9 Hz), 124.4 (d, $J=2.7 \mathrm{~Hz}), 123.1(\mathrm{dd}, J=5.3,3.0 \mathrm{~Hz}), 122.3(\mathrm{~s}), 117.6(\mathrm{~d}, J=17.5 \mathrm{~Hz}), 116.1(\mathrm{~d}, J=22.1 \mathrm{~Hz})$, $115.0(\mathrm{~d}, J=17.6 \mathrm{~Hz}) .{ }^{19} \mathrm{~F}\left(\mathrm{CDCl}_{3}, 282 \mathrm{MHz}\right): \delta-116.0(\mathrm{~s}, 1 \mathrm{~F}),-136.0(\mathrm{~d}, J=20.8 \mathrm{~Hz}, 1 \mathrm{~F})$, $136.8(\mathrm{~d}, J=21.1 \mathrm{~Hz}, 1 \mathrm{~F})$. HRMS (EI) calcd for $\mathrm{C}_{14} \mathrm{H}_{9} \mathrm{~F}_{3}[\mathrm{M}]^{+}:$234.0656; found, 234.0652 .

(E)-1,2-Difluoro-4-(4-methoxystyryl)benzene 26: 66\% yield, white crystals; mp 73-74 ${ }^{\circ} \mathrm{C} ;{ }^{1} \mathrm{H}$ NMR $\left(\mathrm{CDCl}_{3}, 300 \mathrm{MHz}\right): \delta 7.41(\mathrm{~d}, J=8.6 \mathrm{~Hz}, 2 \mathrm{H}), 7.27(\mathrm{~m}, 1 \mathrm{H}), 7.11(\mathrm{~m}, 2 \mathrm{H}), 6.94(\mathrm{~d}, J=$ $16.5 \mathrm{~Hz}, 1 \mathrm{H}), 6.88(\mathrm{~d}, J=8.7 \mathrm{~Hz}, 2 \mathrm{H}), 6.83(\mathrm{~d}, J=16.5 \mathrm{~Hz}, 1 \mathrm{H}), 3.81(\mathrm{~s}, 3 \mathrm{H}) .{ }^{13} \mathrm{C} \mathrm{NMR}\left(\mathrm{CDCl}_{3}\right.$, $75 \mathrm{MHz}): \delta 159.8(\mathrm{~s}), 151.8(\mathrm{dd}, J=79.6,12.7 \mathrm{~Hz}), 148.6(\mathrm{dd}, \mathrm{J}=81.0,13.2 \mathrm{~Hz}), 135.2(\mathrm{t}, J=$ $4.9 \mathrm{~Hz}), 129.6$ (d, $J=13.0 \mathrm{~Hz}), 129.5$ (s), 128.0 (s), 124.5 (s), 122.5 (dd, $J=5.4,2.8 \mathrm{~Hz}$ ), 117.5 $(\mathrm{d}, J=17.4 \mathrm{~Hz}), 114.5(\mathrm{~d}, J=16.0 \mathrm{~Hz}), 114.4(\mathrm{~s}), 55.5(\mathrm{~s}) .{ }^{19} \mathrm{~F}\left(\mathrm{CDCl}_{3}, 282 \mathrm{MHz}\right): \delta-136.4(\mathrm{~d}$, $J=20.9 \mathrm{~Hz}, 1 \mathrm{~F}),-138.1(\mathrm{~d}, J=20.8 \mathrm{~Hz}, 1 \mathrm{~F})$. HRMS (EI) calcd for $\mathrm{C}_{15} \mathrm{H}_{12} \mathrm{~F}_{2} \mathrm{O}[\mathrm{M}]^{+}: 246.0856$; found, 246.0860 .

(E)-1,4-Difluoro-2-(2-fluorostyryl)benzene 29: $88 \%$ yield, white crystals; mp 79-81 ${ }^{\circ} \mathrm{C} ;{ }^{1} \mathrm{H}$ NMR $\left(\mathrm{CDCl}_{3}, 300 \mathrm{MHz}\right): \delta 7.60(\mathrm{dt}, J=7.7,1.6 \mathrm{~Hz}, 1 \mathrm{H}), 7.27(\mathrm{~s}, 2 \mathrm{H}), 7.26(\mathrm{~m}, 2 \mathrm{H}), 7.13$ (dd, $J=7.6$, $1.1 \mathrm{~Hz}, 1 \mathrm{H}), 7.08(\mathrm{~m}, 1 \mathrm{H}), 7.00(\mathrm{~m}, 1 \mathrm{H}), 6.90(\mathrm{~m}, 1 \mathrm{H}) .{ }^{13} \mathrm{C} \mathrm{NMR}\left(\mathrm{CDCl}_{3}, 75 \mathrm{MHz}\right): \delta 160.6(\mathrm{~d}$, $J=250.4 \mathrm{~Hz}), 159.3(\mathrm{~d}, J=185.2 \mathrm{~Hz}), 156.1(\mathrm{~d}, J=189.0 \mathrm{~Hz}), 129.6(\mathrm{~d}, J=8.5 \mathrm{~Hz}), 127.2(\mathrm{~d}, J$ $=2.9 \mathrm{~Hz}), 126.5(\mathrm{dd}, J=14.4,7.9 \mathrm{~Hz}), 124.6(\mathrm{~d}, J=12.0 \mathrm{~Hz}), 124.3(\mathrm{~d}, J=3.3 \mathrm{~Hz}), 124.1(\mathrm{~s})$, $122.0(\mathrm{~s}), 116.8(\mathrm{dd}, J=25.3,8.9 \mathrm{~Hz}), 115.9(\mathrm{~d}, J=22.2 \mathrm{~Hz}), 115.5(\mathrm{dd}, J=24.5,8.8 \mathrm{~Hz}), 112.8$ $(\mathrm{dd}, J=24.7,3.5) .{ }^{19} \mathrm{~F}\left(\mathrm{CDCl}_{3}, 282 \mathrm{MHz}\right): \delta-115.9$ (s, 1F), -117.3 (d, J=17.2 Hz, 1F), -122.4 $(\mathrm{d}, J=17.2 \mathrm{~Hz}, 1 \mathrm{~F})$. HRMS (EI) calcd for $\mathrm{C}_{14} \mathrm{H}_{9} \mathrm{~F}_{3}[\mathrm{M}]^{+}:$234.0656; found, 234.0654 . 
(E)-1,2-Difluoro-4-(3-fluorostyryl)benzene 30: 95\% yield, white crystals; mp $48-49{ }^{\circ} \mathrm{C} ;{ }^{1} \mathrm{H}$ NMR $\left(\mathrm{CDCl}_{3}, 300 \mathrm{MHz}\right): \delta 7.30(\mathrm{~m}, 2 \mathrm{H}), 7.16(\mathrm{~m}, 4 \mathrm{H}), 6.98(\mathrm{~m}, 1 \mathrm{H}), 6.96(\mathrm{~d}, J=16.5 \mathrm{~Hz}, 1 \mathrm{H}), 6.90$ $(\mathrm{d}, J=16.5 \mathrm{~Hz}, 1 \mathrm{H}) .{ }^{13} \mathrm{C} \mathrm{NMR}\left(\mathrm{CDCl}_{3}, 75 \mathrm{MHz}\right): \delta 163.2(\mathrm{~d}, J=245.6 \mathrm{~Hz}), 152.0(\mathrm{dd}, J=42.1$, $11.1 \mathrm{~Hz}), 148.7$ (dd, $J=44.7,11.1 \mathrm{~Hz}), 139.1,(\mathrm{~d}, J=7.8 \mathrm{~Hz}), 134.2(\mathrm{t}, J=5.9 \mathrm{~Hz}), 130.2(\mathrm{~d}, J=$ $8.4 \mathrm{~Hz}), 128.5$ (s), 127.8 (s), $122.9(\mathrm{dd}, J=6.2,3.6 \mathrm{~Hz}), 122.6(\mathrm{~d}, J=2.3 \mathrm{~Hz}), 117.5(\mathrm{~d}, J=17.5$ $\mathrm{Hz}), 114.9(\mathrm{~d}, J=5.3 \mathrm{~Hz}), 114.7(\mathrm{~s}), 112.8(\mathrm{~d}, J=21.9 \mathrm{~Hz}) .{ }^{19} \mathrm{~F}\left(\mathrm{CDCl}_{3}, 282 \mathrm{MHz}\right): \delta-111.4(\mathrm{~s}$, $1 \mathrm{~F}),-135.8(\mathrm{~d}, J=20.9 \mathrm{~Hz}, 1 \mathrm{~F}),-136.5(\mathrm{~d}, J=20.8 \mathrm{~Hz}, 1 \mathrm{~F})$. HRMS (EI) calcd for $\mathrm{C}_{14} \mathrm{H}_{9} \mathrm{~F}_{3}$ $[\mathrm{M}]^{+}:$234.0656; found, 234.0660.

(E)-1,4-Difluoro-2-(3-fluorostyryl)benzene 34: 89\% yield, white crystals; mp 73-74 ${ }^{\circ} \mathrm{C} ;{ }^{1} \mathrm{H}$ NMR $\left(\mathrm{CDCl}_{3}, 300 \mathrm{MHz}\right): \delta 7.27(\mathrm{~m}, 4 \mathrm{H}), 7.18(\mathrm{~d}, J=16.5 \mathrm{~Hz}, 1 \mathrm{H}), 7.06(\mathrm{~d}, J=16.6 \mathrm{~Hz}, 1 \mathrm{H}), 7.01$ $(\mathrm{m}, 2 \mathrm{H}), 6.91(\mathrm{~m}, 1 \mathrm{H}) .{ }^{13} \mathrm{C} \mathrm{NMR}\left(\mathrm{CDCl}_{3}, 75 \mathrm{MHz}\right): \delta 163.2(\mathrm{~d}, J=245.7 \mathrm{~Hz}), 159.3(\mathrm{~d}, J=$ $179.4 \mathrm{~Hz}), 156.0(\mathrm{~d}, J=183.7 \mathrm{~Hz}), 139.0(\mathrm{~d}, J=7.7 \mathrm{~Hz}), 130.8(\mathrm{~s}), 130.2(\mathrm{~d}, J=8.3 \mathrm{~Hz}), 126.1$ $(\mathrm{m}), 122.8(\mathrm{~d}, J=2.0 \mathrm{~Hz}), 121.2(\mathrm{~s}), 116.9(\mathrm{dd}, J=25.3,8.8 \mathrm{~Hz}), 115.5(\mathrm{dd}, J=24.5,8.7 \mathrm{~Hz})$, $115.1(\mathrm{~d}, J=21.6 \mathrm{~Hz}), 113.1(\mathrm{~d}, J=21.9 \mathrm{~Hz}), 112.8(\mathrm{dd}, J=24.6,3.8 \mathrm{~Hz}) .{ }^{19} \mathrm{~F}\left(\mathrm{CDCl}_{3}, 282\right.$ MHz): $\delta-111.5$ (s, 1F), $-117.3(\mathrm{~d}, J=17.2 \mathrm{~Hz}, 1 \mathrm{~F}),-122.0(\mathrm{~d}, J=17.2 \mathrm{~Hz}, 1 \mathrm{~F})$. HRMS (EI) calcd for $\mathrm{C}_{14} \mathrm{H}_{9} \mathrm{~F}_{3}[\mathrm{M}]^{+}$: 234.0656; found, 234.0659.

(E)-2,4-Difluoro-1-(3-fluorostyryl)benzene 35: 67\% yield, white crystals; mp 60-61 ${ }^{\circ} \mathrm{C}$; ${ }^{1} \mathrm{H}$ NMR $\left(\mathrm{CDCl}_{3}, 300 \mathrm{MHz}\right): \delta 7.50(\mathrm{dd}, J=15.0,8.3 \mathrm{~Hz}, 1 \mathrm{H}), 7.23(\mathrm{~m}, 3 \mathrm{H}), 7.16(\mathrm{~d}, J=16.5 \mathrm{~Hz}, 1 \mathrm{H})$, $7.04(\mathrm{~d}, J=16.5 \mathrm{~Hz}, 1 \mathrm{H}), 6.88(\mathrm{~m}, 3 \mathrm{H}) .{ }^{13} \mathrm{C} \mathrm{NMR}\left(\mathrm{CDCl}_{3}, 75 \mathrm{MHz}\right): \delta 163.2(\mathrm{~d}, J=245.5 \mathrm{~Hz})$, $163.1(\mathrm{dd}, J=143.9,12.3 \mathrm{~Hz}), 159.8(\mathrm{dd}, J=146.1,12.2), 139.5(\mathrm{~d}, J=7.6 \mathrm{~Hz}), 130.2(\mathrm{~d}, J=$ $8.4 \mathrm{~Hz}), 129.4(\mathrm{~s}), 128.0(\mathrm{dd}, J=9.4,5.0 \mathrm{~Hz}), 122.5(\mathrm{~d}, J=2.2 \mathrm{~Hz}), 121.3(\mathrm{~s}), 121.1(\mathrm{~d}, J=3.5$ $\mathrm{Hz}), 114.8(\mathrm{~d}, J=21.4 \mathrm{~Hz}), 112.9(\mathrm{~d}, J=21.9 \mathrm{~Hz}), 11.7(\mathrm{dd}, J=22.0,3.7 \mathrm{~Hz}), 104.2(\mathrm{t}, J=25.8$ $\mathrm{Hz}) .{ }^{19} \mathrm{~F}\left(\mathrm{CDCl}_{3}, 282 \mathrm{MHz}\right): \delta-108.6(\mathrm{~d}, J=6.1 \mathrm{~Hz}, 1 \mathrm{~F}),-111.6(\mathrm{~s}, 1 \mathrm{~F}),-111.7(\mathrm{~d}, J=6.3 \mathrm{~Hz}$, 1F). HRMS (EI) calcd for $\mathrm{C}_{14} \mathrm{H}_{9} \mathrm{~F}_{3}[\mathrm{M}]^{+}: 234.0656$; found, 234.0658 .

(E)-2,4-Difluoro-1-(2-fluorostyryl)benzene 36: 70\% yield, white crystals; mp 84-85 ${ }^{\circ} \mathrm{C} ;{ }^{1} \mathrm{H}$ NMR $\left(\mathrm{CDCl}_{3}, 300 \mathrm{MHz}\right): \delta 7.60(\mathrm{t}, J=8.8 \mathrm{~Hz}, 1 \mathrm{H}), 7.58(\mathrm{t}, J=8.7 \mathrm{~Hz}, 1 \mathrm{H}), 7.25(\mathrm{~s}, 2 \mathrm{H}), 7.22(\mathrm{~m}$, $1 \mathrm{H}), 7.13(\mathrm{dt}, J=7.6,1.3 \mathrm{~Hz}, 1 \mathrm{H}), 7.06(\mathrm{dt}, J=9.5,1.3 \mathrm{~Hz}, 1 \mathrm{H}), 6.83(\mathrm{~m}, 2 \mathrm{H}) .{ }^{13} \mathrm{C}$ NMR $\left(\mathrm{CDCl}_{3}, 75 \mathrm{MHz}\right): \delta 162.6(\mathrm{dd}, J=250.5,13.9 \mathrm{~Hz}), 162.3(\mathrm{t}, J=5.1 \mathrm{~Hz}), 158.9(\mathrm{t}, J=10.2 \mathrm{~Hz})$, $129.3(\mathrm{~d}, J=8.4 \mathrm{~Hz}), 128.1(\mathrm{dd}, J=9.5,5.2 \mathrm{~Hz}), 127.2(\mathrm{~d}, J=3.1 \mathrm{~Hz}), 125.1(\mathrm{~d}, J=11.9 \mathrm{~Hz})$, 124.4 (d, $J=3.2 \mathrm{~Hz}$ ), 122.9 (s) 122.2 (s), 121.7 (dd, $J=11.7,3.6 \mathrm{~Hz}), 116.0$ (d, $J=22.2 \mathrm{~Hz}$ ), $111.8(\mathrm{dd}, J=21.6,3.5 \mathrm{~Hz}), 104.3(\mathrm{t}, J=25.7 \mathrm{~Hz}) .{ }^{19} \mathrm{~F}\left(\mathrm{CDCl}_{3}, 282 \mathrm{MHz}\right): \delta-108.8(\mathrm{~s}, 1 \mathrm{~F}),-$ $112.2(\mathrm{~d}, J=5.6 \mathrm{~Hz}, 1 \mathrm{~F}),-116.4(\mathrm{~s}, 1 \mathrm{~F})$. HRMS (EI) calcd for $\mathrm{C}_{14} \mathrm{H}_{9} \mathrm{~F}_{3}[\mathrm{M}]^{+}: 234.0656$; found, 234.0658 .

(E)-2,4-Difluoro-1-(4-methylstyryl)benzene 37: $32 \%$ yield, white crystals; mp $72-73{ }^{\circ} \mathrm{C} ;{ }^{1} \mathrm{H}$ NMR $\left(\mathrm{CDCl}_{3}, 300 \mathrm{MHz}\right): \delta 7.55(\mathrm{dd}, J=15.0,8.4 \mathrm{~Hz}, 1 \mathrm{H}), 7.89(\mathrm{~d}, J=7.9 \mathrm{~Hz}, 2 \mathrm{H}), 7.47(\mathrm{~d}, J=$ $7.5 \mathrm{~Hz}, 2 \mathrm{H}), 7.16(\mathrm{~d}, J=16.5 \mathrm{~Hz}, 1 \mathrm{H}), 7.07(\mathrm{~d}, J=16.5 \mathrm{~Hz}, 1 \mathrm{H}), 6.85(\mathrm{~m}, 2 \mathrm{H}), 2.35(\mathrm{~s}, 3 \mathrm{H}) .{ }^{13} \mathrm{C}$ 
NMR $\left(\mathrm{CDCl}_{3}, 75 \mathrm{MHz}\right): \delta 162.9(\mathrm{dd}, J=131.0,12.1 \mathrm{~Hz}), 159.5(\mathrm{dd}, J=133.5,12.0 \mathrm{~Hz}), 137.9$ (s), $134.3(\mathrm{~s}), 130.5(\mathrm{~s}), 129.5$ (s), 127.7 (dd, $J=9.2,5.4 \mathrm{~Hz}), 126.5$ (s), 121.8 (dd, $J=12.5,3.8$ $\mathrm{Hz}), 118.9$ (s), 111.5 (dd, $J=21.5,2.8 \mathrm{~Hz}), 104.1(\mathrm{t}, \mathrm{J}=25.7 \mathrm{~Hz}), 21.4(\mathrm{~s}) .{ }^{19} \mathrm{~F}\left(\mathrm{CDCl}_{3}, 282\right.$ MHz): $\delta-109.7$ (d, $J=5.3 \mathrm{~Hz}, 1 \mathrm{~F}),-112.4$ (d, $J=4.4 \mathrm{~Hz}, 1 \mathrm{~F}$ ). HRMS (EI) calcd for $\mathrm{C}_{15} \mathrm{H}_{12} \mathrm{~F}_{2}$ $[\mathrm{M}]^{+}: 230.0907$; found, 230.0912 .

(E)-1,4-Difluoro-2-(4-fluorostyryl)benzene 40: 50\% yield, buff crystals; $\mathrm{mp} 76-77{ }^{\circ} \mathrm{C} ;{ }^{1} \mathrm{H}$ NMR $\left(\mathrm{CDCl}_{3}, 300 \mathrm{MHz}\right): \delta 7.48(\mathrm{dd}, J=8.5,5.5 \mathrm{~Hz}, 2 \mathrm{H}), 7.25(\mathrm{~m}, 1 \mathrm{H}), 7.09(\mathrm{~s}, 2 \mathrm{H}), 7.00(\mathrm{~m}, 3 \mathrm{H})$, $6.90(\mathrm{~m}, 1 \mathrm{H}) .{ }^{13} \mathrm{C} \mathrm{NMR}\left(\mathrm{CDCl}_{3}, 75 \mathrm{MHz}\right): \delta 162.8(\mathrm{~d}, J=248.3 \mathrm{~Hz}), 159.2(\mathrm{~d}, J=190.6 \mathrm{~Hz})$, $156.0(\mathrm{~d}, J=192.8 \mathrm{~Hz}), 132.9(\mathrm{~d}, J=3.0 \mathrm{~Hz}), 130.7(\mathrm{~d}, J=4.3 \mathrm{~Hz}), 128.3(\mathrm{~d}, J=8.0 \mathrm{~Hz}), 126.5$ $(\mathrm{m}), 119.7$ (s), 116.8 (dd, $J=25.3,8.9 \mathrm{~Hz}), 115.7(\mathrm{~d}, J=21.8 \mathrm{~Hz}), 115.1$ (dd, $J=24.6,8.9 \mathrm{~Hz})$, $112.7(\mathrm{dd}, J=24.7,3.0 \mathrm{~Hz}) .{ }^{19} \mathrm{~F}\left(\mathrm{CDCl}_{3}, 282 \mathrm{MHz}\right): \delta-111.5(\mathrm{~s}, 1 \mathrm{~F}),-117.4(\mathrm{~d}, J=17.0 \mathrm{~Hz}, 1 \mathrm{~F})$, $-122.5(\mathrm{~d}, J=16.9 \mathrm{~Hz}, 1 \mathrm{~F})$. HRMS (EI) calcd for $\mathrm{C}_{14} \mathrm{H}_{9} \mathrm{~F}_{3}[\mathrm{M}]^{+}: 234.0656$; found, 234.0659 .

(E)-1,2-Dimethoxy-3-(4-methylstyryl)benzene 48: 92\% yield, white crystals; mp 38-40 ${ }^{\circ} \mathrm{C} ;{ }^{1} \mathrm{H}$ NMR $\left(\mathrm{CDCl}_{3}, 300 \mathrm{MHz}\right): \delta 7.43(\mathrm{~d}, J=7.7 \mathrm{~Hz}, 2 \mathrm{H}), 7.41(\mathrm{~d}, J=16.7 \mathrm{~Hz}, 1 \mathrm{H}), 7.22(\mathrm{~d}, J=7.8$ $\mathrm{Hz}, 1 \mathrm{H}), 7.14(\mathrm{~d}, J=7.9 \mathrm{~Hz}, 2 \mathrm{H}), 7.08(\mathrm{~d}, J=16.6 \mathrm{~Hz}, 1 \mathrm{H}), 7.02(\mathrm{t}, J=8.2 \mathrm{~Hz}, 1 \mathrm{H}), 6.79(\mathrm{~d}, J=$ $7.3 \mathrm{~Hz}, 1 \mathrm{H}), 3.83(\mathrm{~s}, 6 \mathrm{H}), 2.34(\mathrm{~s}, 3 \mathrm{H}) .{ }^{13} \mathrm{C} \mathrm{NMR}\left(\mathrm{CDCl}_{3}, 75 \mathrm{MHz}\right): \delta 153.1,146.8,137.5$, 134.9, 131.7, 129.8, 129.3, 126.6, 124.1, 121.9, 117.8, 111.1, 61.0, 55.7, 21.2. HRMS (EI) calcd for $\mathrm{C}_{17} \mathrm{H}_{18} \mathrm{O}_{3}[\mathrm{M}]^{+}$: 270.1256; found, 270.1258 .

(E)-1-Methoxy-2-(3-methoxystyryl)benzene 49: 86\% yield, white crystals; mp 49-50 ${ }^{\circ} \mathrm{C} ;{ }^{1} \mathrm{H}$ NMR $\left(\mathrm{CDCl}_{3}, 300 \mathrm{MHz}\right): \delta 7.55(\mathrm{~d}, J=7.6 \mathrm{~Hz}, 1 \mathrm{H}), 7.48(\mathrm{~d}, J=16.5 \mathrm{~Hz}, 1 \mathrm{H}), 7.23(\mathrm{t}, J=7.7 \mathrm{~Hz}$, $1 \mathrm{H}), 7.18$ (t, $J=7.4 \mathrm{~Hz}, 1 \mathrm{H}), 7.09(\mathrm{~d}, J=8.9 \mathrm{~Hz}, 1 \mathrm{H}), 7.06(\mathrm{~d}, J=16.6 \mathrm{~Hz}, 1 \mathrm{H}), 7.05(\mathrm{~s}, 1 \mathrm{H})$, $6.92(\mathrm{t}, J=7.4 \mathrm{~Hz}, 1 \mathrm{H}), 6.83(\mathrm{~d}, J=8.2 \mathrm{~Hz}, 1 \mathrm{H}), 6.76(\mathrm{dd}, J=8.0,1.9 \mathrm{~Hz}, 1 \mathrm{H}), 3.80(\mathrm{~s}, 3 \mathrm{H})$, $3.76(\mathrm{~s}, 3 \mathrm{H}) .{ }^{13} \mathrm{C} \mathrm{NMR}\left(\mathrm{CDCl}_{3}, 75 \mathrm{MHz}\right): \delta 159.8,156.9,139.4,129.5,128.9,128.7,126.4$, 126.2, 123.8, 120.7 119.3, 113.0, 111.7, 110.9, 55.4, 55.1. HRMS (EI) calcd for $\mathrm{C}_{16} \mathrm{H}_{16} \mathrm{O}_{2}[\mathrm{M}]^{+}$: 240.1150; found, 240.1156 .

(E)-1,4-Dimethoxy-2-(3-methoxystyryl)benzene 50: 96\% yield, white crystals; $\mathrm{mp} 48-49{ }^{\circ} \mathrm{C} ;{ }^{1} \mathrm{H}$ NMR (CDCl $3,300 \mathrm{MHz}): \delta 7.44(\mathrm{~d}, J=16.4 \mathrm{~Hz}, 1 \mathrm{H}), 7.24(\mathrm{t}, J=7.9 \mathrm{~Hz}, 1 \mathrm{H}), 7.10(\mathrm{~m}, 3 \mathrm{H})$, $7.05(\mathrm{~d}, J=16.4 \mathrm{~Hz}, 1 \mathrm{H}), 6.78(\mathrm{~m}, 3 \mathrm{H}), 3.81(\mathrm{~s}, 3 \mathrm{H}), 3.80(\mathrm{~s}, 3 \mathrm{H}), 3.78(\mathrm{~s}, 3 \mathrm{H}) .{ }^{13} \mathrm{C}$ NMR $\left(\mathrm{CDCl}_{3}, 75 \mathrm{MHz}\right): \delta 159.9,153.8,151.5,139.3,129.5,129.2,127.1,123.6,119.4,113.8,113.2$, 112.3, 111.8, 111.7, 56.2, 55.7, 55.2. HRMS (EI) calcd for $\mathrm{C}_{17} \mathrm{H}_{18} \mathrm{O}_{3}[\mathrm{M}]^{+}: 270.1256$; found, 270.1258 .

(E)-1,2-Dimethoxy-3-(4-(trifluoromethyl)styryl)benzene 54: 84\% yield, white crystals; mp 67-69 ${ }^{\circ} \mathrm{C} ;{ }^{1} \mathrm{H} \mathrm{NMR}\left(\mathrm{CDCl}_{3}, 300 \mathrm{MHz}\right): \delta 7.62(\mathrm{~d}, J=9.3 \mathrm{~Hz}, 2 \mathrm{H}), 7.59(\mathrm{~d}, J=9.7 \mathrm{~Hz}, 2 \mathrm{H}), 7.54(\mathrm{~d}, J=$ $16.7 \mathrm{~Hz}, 1 \mathrm{H}), 7.24(\mathrm{~d}, J=7.8 \mathrm{~Hz}, 1 \mathrm{H}), 7.13(\mathrm{~d}, J=16.6 \mathrm{~Hz}, 1 \mathrm{H}), 7.07(\mathrm{t}, J=8.0 \mathrm{~Hz}, 1 \mathrm{H}), 6.87$ $(\mathrm{d}, J=8.0 \mathrm{~Hz}, 1 \mathrm{H}), 3.88$ (s, 3H), 3.87 (s, 3H). ${ }^{13} \mathrm{C} \mathrm{NMR}\left(\mathrm{CDCl}_{3}, 75 \mathrm{MHz}\right): \delta 153.1,147.3$, 
141.2, 130.9, 128.3, 126.7, 125.6, 125.5, 124.2, 118.0, 112.0, 61.3, 56.0. ${ }^{19} \mathrm{~F}\left(\mathrm{CDCl}_{3}, 282 \mathrm{MHz}\right)$ : $\delta$-60.9 (s, 3F). HRMS (EI) calcd for $\mathrm{C}_{17} \mathrm{H}_{15} \mathrm{~F}_{3} \mathrm{O}_{2}[\mathrm{M}]^{+}:$308.3002; found, 308.3000 .

(E)-1-(4-Isopropylstyryl)-2,3-dimethoxybenzene 55: 96\% yield, oil; ${ }^{1} \mathrm{H} \mathrm{NMR}\left(\mathrm{CDCl}_{3}, 300 \mathrm{MHz}\right)$ : $\delta 7.35(\mathrm{~d}, J=8.2 \mathrm{~Hz}, 2 \mathrm{H}), 7.26(\mathrm{~d}, J=16.5 \mathrm{~Hz}, 1 \mathrm{H}), 7.24(\mathrm{dd}, J=6.3,1.6 \mathrm{~Hz}, 1 \mathrm{H}), 7.17(\mathrm{~d}, J=$ $8.1 \mathrm{~Hz}, 2 \mathrm{H}), 7.14(\mathrm{~d}, J=16.5 \mathrm{~Hz}, 1 \mathrm{H}), 7.07(\mathrm{t}, J=8.0 \mathrm{~Hz}, 1 \mathrm{H}), 6.84(\mathrm{dd}, J=8.1,1.2 \mathrm{~Hz}, 1 \mathrm{H})$, 3.89 (s, 3H), 3.87 (s, 3H), 2.94 (sept, $J=6.9 \mathrm{~Hz}, 1 \mathrm{H}), 1.30$ (d, $J=6.9 \mathrm{~Hz}, 6 \mathrm{H}) .{ }^{13} \mathrm{C}$ NMR $\left(\mathrm{CDCl}_{3}, 75 \mathrm{MHz}\right): \delta$ 153.1, 148.5, 146.8, 135.3, 131.8, 129.8, 126.7, 126.6, 124.1, 122.0, 117.8, 111.1, 61.0, 55.7, 33.9, 23.9. HRMS (EI) calcd for $\mathrm{C}_{19} \mathrm{H}_{22} \mathrm{O}_{2}[\mathrm{M}]^{+}: 282.1620$; found, 282.1618.

\section{Acknowledgments}

This work was supported in part by grant BC043125 from the U.S. Army/DOD Breast Cancer Program. 
Table 1

Structures of (E)-Stilbenes ${ }^{\mathrm{a}}$

\begin{tabular}{|c|c|c|c|c|c|c|c|}
\hline Product & $\mathrm{R}_{1}$ & $\mathrm{R}_{2}$ & Reference $^{\mathrm{b}}$ & Product & $\mathrm{R}_{1}$ & $\mathrm{R}_{2}$ & Reference $^{b}$ \\
\hline 1 & $4-\mathrm{OCH}_{3}$ & $2-\mathrm{F}$ & 21 & $29 *$ & $2-\mathrm{F}$ & 2,5-diF & - \\
\hline 2 & - & $2-\mathrm{F}$ & 21 & $30 *$ & $3-\mathrm{F}$ & 3,4-diF & - \\
\hline 3 & - & $3-\mathrm{F}$ & 21 & 31 & $2-\mathrm{F}$ & 2,6-diF & 35 \\
\hline 4 & - & $4-\mathrm{F}$ & 21 & 32 & $3-\mathrm{F}$ & $3-\mathrm{F}$ & 31 \\
\hline 5 & $4-\mathrm{OCH}_{3}$ & $3-\mathrm{F}$ & 21 & 33 & $3-\mathrm{F}$ & $4-\mathrm{F}$ & 36 \\
\hline 6 & $4-\mathrm{OCH}_{3}$ & $4-F$ & 21 & $34^{*}$ & $3-F$ & 2,5-diF & - \\
\hline 7 & $4-\mathrm{CH}_{3}$ & $4-\mathrm{F}$ & 28 & $35^{*}$ & $3-\mathrm{F}$ & 2,4-diF & - \\
\hline 8 & $4-\mathrm{CH}_{3}$ & $3-\mathrm{F}$ & 28 & $36^{*}$ & $2-\mathrm{F}$ & 2,4-diF & - \\
\hline 9 & $4-\mathrm{CH}_{3}$ & $2-\mathrm{F}$ & 28 & $37 *$ & $4-\mathrm{CH}_{3}$ & 2,4-diF & - \\
\hline $10 *$ & $2-\mathrm{F}$ & $2-\mathrm{OCH}_{3}$ & - & 38 & $4-\mathrm{F}$ & $2,4-\mathrm{diF}$ & 39 \\
\hline 11 & $3-\mathrm{OCH}_{3}$ & $2-\mathrm{F}$ & 29 & 39 & $4-\mathrm{F}$ & 3,4-diF & 39 \\
\hline 12 & $3-\mathrm{OCH}_{3}$ & $4-\mathrm{F}$ & 30 & $40 *$ & $4-F$ & 2,5-diF & - \\
\hline 13 & $3-\mathrm{OCH}_{3}$ & $3-\mathrm{F}$ & 31 & 41 & - & 2,3- $\mathrm{diOCH}_{3}$ & 21 \\
\hline 14 & $3-\mathrm{F}$ & 3,4-diOCH 3 & 32 & 42 & - & $2-\mathrm{OCH}_{3}$ & 21 \\
\hline 15 & $4-F$ & 3,4- $\mathrm{diOCH}_{3}$ & 33 & 43 & $4-\mathrm{OCH}_{3}$ & 2,4- $\mathrm{diOCH}_{3}$ & 21 \\
\hline $16^{*}$ & $3-F$ & $2,3-\mathrm{diOCH}_{3}$ & - & 44 & $4-\mathrm{OCH}_{3}$ & $2-\mathrm{Cl}$ & 21 \\
\hline $17 *$ & $4-\mathrm{F}$ & 2,3- $\mathrm{diOCH}_{3}$ & - & 45 & $4-\mathrm{OCH}_{3}$ & $3-\mathrm{OH}$ & 34 \\
\hline $18 *$ & $4-\mathrm{F}$ & $2,5-\mathrm{diOCH}_{3}$ & - & 46 & $4-\mathrm{OCH}_{3}$ & $3-\mathrm{OCH}_{3}, 4-\mathrm{OH}$ & 40 \\
\hline 19 & $4-\mathrm{Cl}$ & $2-\mathrm{F}$ & 29 & 47 & $4-\mathrm{CH}_{3}$ & $3-\mathrm{CF}_{3}$ & 31 \\
\hline 20 & $4-\mathrm{OH}$ & $2-\mathrm{F}$ & 34 & $48^{*}$ & $2,3-\mathrm{OCH}_{3}$ & $4-\mathrm{CH}_{3}$ & - \\
\hline 21 & - & 2,6-diF & 35 & $49 *$ & $3-\mathrm{OCH}_{3}$ & $2-\mathrm{OCH}_{3}$ & - \\
\hline $22 *$ & $4-\mathrm{CH}_{3}$ & 3,4-diF & - & $50 *$ & $3-\mathrm{OCH}_{3}$ & $2,5-\mathrm{diOCH}_{3}$ & - \\
\hline $23^{*}$ & $4-\mathrm{OCH}_{3}$ & 2,5-diF & - & 51 & $4-\mathrm{OCH}_{3}$ & $3-\mathrm{NO}_{2}$ & 41 \\
\hline $24 *$ & $2-\mathrm{F}$ & 3,4-diF & - & 52 & - & $3-\mathrm{NO}_{2}$ & 42 \\
\hline 25 & $2-\mathrm{F}$ & $3-\mathrm{F}$ & 36 & 53 & $4-\mathrm{CH}_{3}$ & $3-\mathrm{NO}_{2}$ & 43 \\
\hline $26^{*}$ & $4-\mathrm{OCH}_{3}$ & 3,4-diF & - & $54^{*}$ & 2,3- $\mathrm{diOCH}_{3}$ & $4-\mathrm{CF}_{3}$ & - \\
\hline 27 & $2-\mathrm{F}$ & $2-\mathrm{F}$ & 37 & $55^{*}$ & $2,3-\mathrm{diOCH}_{3}$ & 4- $\mathrm{CH}\left(\mathrm{CH}_{3}\right)_{2}$ & - \\
\hline 28 & $4-F$ & $2-\mathrm{F}$ & 38 & 56 & 2,4-diOCH${ }_{3}$ & 2,5- $\mathrm{diOCH}_{3}$ & 44 \\
\hline
\end{tabular}

${ }^{a}$ data for starred compounds is reported in the experimental section

${ }^{b}$ melting points and NMR data of known compounds are in agreement with the literature data 
Table 2. Activation of Nrf2 by monofluoro trans stilbenes

\begin{tabular}{|c|c|c|c|}
\hline Number & Structure & $\mathrm{EC}_{50}(\mu \mathrm{M})$ & $\begin{array}{c}\text { Fold } \\
\text { activation }\end{array}$ \\
\hline Sulforaphane & & $1.2 \pm 0.08$ & $12.4 \pm 0.3$ \\
\hline Resveratrol & & $5.4 \pm 0.5$ & $3.2 \pm 0.2$ \\
\hline 1 (LD55) & & $5.4 \pm 0.3$ & $14.9 \pm 1.2$ \\
\hline 2 & & $0.7 \pm 0.1$ & $10.7 \pm 0.6$ \\
\hline 3 & & $3.1 \pm 0.4$ & $4.9 \pm 2.3$ \\
\hline 4 & & $12.4 \pm 0.5$ & $4.8 \pm 0.3$ \\
\hline 5 & & $8.9 \pm 0.9$ & $3.6 \pm 0.2$ \\
\hline 6 & & $4.2 \pm 0.4$ & $1.7 \pm 0.1$ \\
\hline 7 & & $1.3 \pm 0.2$ & $1.1 \pm 0.2$ \\
\hline 8 & & $0.8 \pm 0.08$ & $4.7 \pm 0.03$ \\
\hline 9 & & $1.4 \pm 0.2$ & $10.1 \pm 0.5$ \\
\hline 10 & & $3.1 \pm 0.2$ & $18.4 \pm 0.6$ \\
\hline 11 & & $3.8 \pm 0.2$ & $14.4 \pm 0.4$ \\
\hline 12 & & $6.0 \pm 0.5$ & $4.4 \pm 0.8$ \\
\hline 13 & $\mathrm{H}_{3} \mathrm{CO}$ & $2.3 \pm 0.5$ & $15.1 \pm 0.8$ \\
\hline 14 & & $9.5 \pm 0.7$ & $5.9 \pm 0.7$ \\
\hline 15 & & $2.6 \pm 0.5$ & $1.6 \pm 0.02$ \\
\hline 16 & & $1.9 \pm 0.1$ & $19.4 \pm 0.5$ \\
\hline 17 & & $2.9 \pm 0.1$ & $16.9 \pm 0.5$ \\
\hline 18 & & $5.1 \pm 0.5$ & $10.7 \pm 0.5$ \\
\hline
\end{tabular}




\begin{tabular}{|l|l|l|l|}
\hline 19 & $1.6 \pm 0.2$ & $5.3 \pm 0.05$ \\
\hline 20 & & $11.4 \pm 1.6$ & $13.4 \pm 1.3$ \\
\hline
\end{tabular}


Table 3. Activation of Nrf2 by polyfluoro trans stilbenes

\begin{tabular}{|c|c|c|c|}
\hline Number & Structure & $\mathrm{EC}_{50}(\mu \mathrm{M})$ & $\begin{array}{c}\text { Fold } \\
\text { activation }\end{array}$ \\
\hline 21 & & $6.9 \pm 0.1$ & $11.4 \pm 0.4$ \\
\hline 22 & & $2.6 \pm 0.18$ & $10.2 \pm 0.2$ \\
\hline 23 & & $3.2 \pm 0.5$ & $17.0 \pm 0.9$ \\
\hline 24 & & $>15$ & $11.5 \pm 2.0^{\mathrm{a}}$ \\
\hline 25 & & $>15$ & $8.5 \pm 0.2^{\mathrm{a}}$ \\
\hline 26 & & $>15$ & $4.6 \pm 0.6^{a}$ \\
\hline 27 & & $4.3 \pm 0.4$ & $13.9 \pm 0.9$ \\
\hline 28 & & $3.6 \pm 0.3$ & $12.7 \pm 0.4$ \\
\hline 29 & & $5.9 \pm 0.2$ & $22.3 \pm 0.5$ \\
\hline 30 & & $5.0 \pm 0.1$ & $12.2 \pm 0.8$ \\
\hline 31 & & $1.4 \pm 0.5$ & $21.2 \pm 2.0$ \\
\hline 32 & & $1.0 \pm 0.12$ & $7.0 \pm 0.7$ \\
\hline 33 & & $0.65 \pm 0.12$ & $4.5 \pm 0.4$ \\
\hline 34 & & $0.3 \pm 0.02$ & $10.7 \pm 1.0$ \\
\hline 35 & & $0.45 \pm 0.01$ & $8.2 \pm 0.2$ \\
\hline 36 & & $9.6 \pm 0.14$ & $5.0 \pm 0.8$ \\
\hline 37 & & $2.0 \pm 0.07$ & $13.5 \pm 0.2$ \\
\hline 38 & & $0.9 \pm 0.08$ & $16.8 \pm 1.8$ \\
\hline 39 & & $>15$ & $7.0 \pm 0.5^{a}$ \\
\hline 40 & & $2.9 \pm 0.59$ & $11.2 \pm 0.1$ \\
\hline
\end{tabular}

a. Fold activation at $15 \mu \mathrm{M}$ 
Table 4. Activation of Nrf2 by nonfluoro trans stilbenes

\begin{tabular}{|c|c|c|c|}
\hline Number & Structure & $\mathrm{EC}_{50}(\mu \mathrm{M})$ & $\begin{array}{c}\text { Fold } \\
\text { activation }\end{array}$ \\
\hline 41 & & $4.7 \pm 0.7$ & $25.4 \pm 0.1$ \\
\hline 42 & & $4.4 \pm 0.1$ & $23.1 \pm 0.6$ \\
\hline 43 & & $4.6 \pm 0.4$ & $15.6 \pm 2.0$ \\
\hline 44 & & $3.1 \pm 0.2$ & $17.8 \pm 0.7$ \\
\hline 45 & & $>15$ & $28.1 \pm 0.1^{a}$ \\
\hline 46 & & $3.7 \pm 0.5$ & $27.7 \pm 1.1$ \\
\hline 47 & & $1.5 \pm 0.5$ & $19.2 \pm 1.1$ \\
\hline 48 & $\mathrm{H}_{3} \mathrm{CO}_{Y}$ & $1.1 \pm 0.2$ & $16.1 \pm 2.3$ \\
\hline 49 & & $4.4 \pm 0.2$ & $29.2 \pm 1.2$ \\
\hline 50 & & $>15$ & $15.7 \pm 3.2^{\mathrm{a}}$ \\
\hline 51 & $\mathrm{H}_{3} \mathrm{CO}$ & $3.3 \pm 0.4$ & $69.0 \pm 1.6$ \\
\hline 52 & & $3.0 \pm 0.4$ & $18.6 \pm 0.5$ \\
\hline 53 & & $3.7 \pm 0.2$ & $11.9 \pm 2.1$ \\
\hline 54 & $\mathrm{H}_{3} \mathrm{CO} \mathrm{OCH}_{3} \mathrm{CF}^{\mathrm{CF}_{3}}$ & $2.2 \pm 0.1$ & $65.5 \pm 2.5$ \\
\hline 55 & $\mathrm{H}_{3} \mathrm{CO} \mathrm{OCH}^{\mathrm{CH}\left(\mathrm{CH}_{3}\right)_{2}}$ & $2.7 \pm 0.3$ & $33.9 \pm 0.7$ \\
\hline 56 & $\overbrace{\mathrm{H}_{3} \mathrm{CO}}^{\mathrm{CH}_{3}}$ & $0.8 \pm 0.03$ & $12.9 \pm 1.2$ \\
\hline
\end{tabular}

a. Fold activation at $15 \mu \mathrm{M}$ 